\title{
"O FURO A QUALQUER PREÇO": PRÁTICAS DISCURSIVAS DE PODER E RESISTÊNCIA ANTE ATITUDES MACHISTAS EM CENÁRIO DE DEMOCRACIA FRÁGIL
}

\author{
"THE SCOOP AT ANY PRICE": DISCURSIVE PRACTICES \\ OF POWER AND RESISTANCE CENTERED ON MALE \\ CHAUVINISM AS A SIGN OF DEMOCRATIC FRAGILITY
}

\author{
Marluce Pereira da Silva* \\ Cid Augusto da Escóssia Rosado**
}

\section{RESUMO}

A jornalista Patrícia Campos Mello, da Folba de S.Paulo, foi envolvida em uma polêmica a partir do depoimento de Hans River do Rio Nascimento à Comissão Parlamentar Mista de Inquérito (CPMI) das Fake News, no Congresso Nacional brasileiro. Ex-funcionário da Yacows, empresa de marketing digital que atuou na campanha de Jair Messias Bolsonaro à presidência da República, o depoente acusou a repórter de lhe oferecer sexo em troca de matéria. O presidente, suposto alvo da investigação jornalística conduzida por Patrícia, a serviço da Folha, apropriou-se da fala de River para declarar que "Ela queria dar o furo a qualquer preço contra mim". Tais afirmações alimentaram manifestações machistas de cunho sexual contra a jornalista, nas redes sociais, levando-a a reagir com a publicação do artigo intitulado "Depoimento: No Brasil, ser mulher nos transforma em alvo de ataques". Com base nesse episódio, objetiva-se, em primeiro plano, abordar a evolução do conceito de democracia e de direitos fundamentais, debatendo como práticas discursivas que expressam sentidos de violência em função do gênero indiciam sintomas de fragilidade democrática. De maneira específica, com amparo em metodologia de análise do discurso de inspiração foucaultiana, investigam-se a formação sócio-histórica dos enunciados, as verdades valorizadas nas produções discursivas dos contendores e as relações de poder e resistência estabelecidas entre eles. Os resultados apontam para a compreensão de que, nas democracias frágeis, discursividades centradas no gênero emergem efeitos de sentidos reveladores não só de estratégias de poder e dominação, mas também de táticas de resistência e transformação. Palavras-chave: discurso; democracia; gênero; poder; resistência.

\footnotetext{
* Universidade Federal da Paraíba, UFPB, João Pessoa, PB, Brasil marlucepereira@uol.com.br Orcid:

** Doutorando no Programa de Pós-Graduação em Estudos da Linguagem (PPgEL) da Universidade Federal do Rio Grande do Norte, UFRN, Natal, RN, Brasil. cidaugusto@gmail.com. Orcid:
} 


\begin{abstract}
Journalist Patrícia Campos Mello, from Folha de S.Paulo, was involved in a controversy based on the testimony of Hans River do Rio Nascimento to the Comission of Fake News, held by Parliamentary Inquiry Commission at Brazilian National Congress. A Yacows' employee, digital marketing company, hired by Jair's presidential campaign. The witness accused the reporter of offering him sex in exchange of detailed information. The president Jair Bolsonaro, supposedly the target of the journalistic investigation conducted by Patrícia, appropriated River's speech to declare that "She was willing to give the scoop at any price against me". Such statements, and debauchery tone used by the president, brought out macho manifestation of a sexual meaning against the journalist, on social networks, leading her to publish an article entitled "Testimony: In Brazil, being a woman makes us the target of attacks". Based on this episode, the main purpose of this article is to address the evolution of the concept of democracy and fundamental rights, debating how discursive practices express the meanings of violence based on gender as an indication of democratic fragility. Specifically, based on Foucault's discourse analysis, the formation of both statements is investigated by the truths valued in the discursive productions, considering the power and resistance established between them. The results found pointed to the comprehension of, in fragile democracies, discourses based on gender emerge effects of revealing meanings not only of strategies of power and domination, but also of tactics of resistance and transformation.
\end{abstract}

Keywords: discourse; democracy; gender; power; resistance.

\title{
INTRODUÇÃO
}

O Congresso Nacional brasileiro criou uma Comissão Parlamentar Mista de Inquérito (CPMI) em junho de 2019, conhecida como CPMI das Fake News, para investigar supostos atentados cibernéticos à democracia, episódios de bullying virtual, a criação de usuários robôs em redes sociais para interferir nas eleições do ano anterior e o aliciamento de menores para a prática de suicídio e crimes de ódio.

Várias testemunhas foram ouvidas, entre elas Hans River do Rio Nascimento, intimado a prestar esclarecimentos por haver sido mencionado como fonte de matéria da Folba de S.Paulo, assinada pelos repórteres Artur Rodrigues e Patrícia Campos Mello. O conteúdo jornalístico abordava supostas revelações de Hans sobre o registro de chips de celular com o uso de nome e CPF de idosos a fim de criar usuários robôs e possibilitar o envio de mensagens falsas em massa, via WhatsApp. A responsável pelo esquema seria a Yacows, empregadora do depoente em 2018, quando a citada empresa prestava serviços de mídia digital à campanha de Jair Bolsonaro à presidência da República.

Questionado, Hans confirmou tais fatos. Negou, contudo, o fornecimento de informações à Folba e fez considerações sobre o contato com a repórter, a quem acusou de "querer um determinado tipo de matéria a troco de sexo" (NASCIMENTO, 
2020, n.p.). O presidente, suposto alvo da investigação jornalística, apropriou-se da fala de River para declarar que "Ela queria dar o furo a qualquer preço contra mim" (BOLSONARO, 2020, n.p.).

Em decorrência dessas investidas, Patrícia (2020, n.p.) começou a receber insultos de cunho sexual proferidos e repercutidos nas redes sociais, reagindo por meio do artigo intitulado Depoimento: No Brasil, ser mulher nos transforma em alvo de ataques. Em sua defesa, saíram veículos de comunicação, colegas de profissão, entidades ligadas à imprensa, a Ordem dos Advogados do Brasil (OAB), partidos políticos e diversas outras instituições, inclusive no plano internacional.

Com base nesse episódio, objetiva-se, em primeiro plano, abordar a evolução do conceito de democracia e de direitos fundamentais, debatendo como práticas discursivas que expressam sentidos de violência em função do gênero indiciam sintoma de fragilidade democrática. De maneira específica, com amparo em metodologia de análise do discurso de inspiração foucaultiana, investigam-se a formação sócio-histórica dos enunciados, as verdades valorizadas nas produções discursivas dos contendores e as relações de poder e resistência estabelecidas.

Assume-se uma postura teórica interdisciplinar, amparada em autores do campo dos estudos da linguagem, da política e das ciências sociais aplicadas, em especial os voltados para a condição da mulher e seu papel nas relações de poder, a partir da materialização da resistência. Serve-se, por exemplo, de Foucault (2004, 2005, 2006, 2007, 2013 e 2014), de quem são extraídas teses sobre relações de poder, resistência e verdade; em Alexi (2015), Bobbio (1986), Santos (2016) e Tavares (2020), quanto à democracia; em Barreda (2012) e Butler (2003, 2015), na caracterização das relações de gênero; e em Traquina (2005) para compreender o papel da mídia no contexto dos fatos pesquisados.

O trabalho foi desenvolvido em três etapas. Na primeira, aborda-se a evolução do conceito de democracia e dos direitos fundamentais, demonstrando que a violência em função do gênero é um sintoma de fragilidade democrática. $\mathrm{Na}$ segunda, concepções foucaultianas sobre discurso e resistência nas relações de poder são contextualizadas na análise dos discursos de verdade emergentes. Na terceira, promove-se a abordagem do corpus, sequenciando-se a descrição dos tipos de discurso percebidos nos enunciados e o exame das condições de seu surgimento.

A pesquisa se insere entre os estudos que buscam compreender as práticas sociais da linguagem e seus resultados apontam para a compreensão de que, nas democracias frágeis, discursividades centradas no gênero emergem como estratégias de poder e dominação, mas também como tática de resistência e transformação. 


\section{GÊNERO E FRAGILIDADE DEMOCRÁTICA}

As ofensas dirigidas a Patrícia Campos Mello são sintomas da fragilidade democrática brasileira. Tal afirmação, que pode soar estranho a indivíduos imersos em culturas que não enxergam a violência de gênero como ruptura dos princípios da igualdade, da liberdade e da dignidade humana, é facilmente demonstrada à luz de teorias das ciências sociais aplicadas, da política e da linguagem.

Gênero é entendido aqui como "construção social e histórica de caráter relacional, configurada a partir das significações e da simbolização cultural de diferenças anatômicas entre homens e mulheres". Dele, decorrem "relações, papéis e identidades ativamente construídas por sujeitos ao longo de suas vidas... reproduzindo relações de desigualdade social e de dominação/subordinação" (BARREDA, 2012, p. 101).

Em complemento, de acordo com Butler (2003, p. 22), "Não é nem o resultado causal do sexo, nem tampouco tão aparentemente fixo quanto o sexo", pois, enquanto a definição sexual binária entre masculino e feminino é biológica, "o gênero é culturalmente constituído" e comporta múltiplas influências.

A construção do gênero envolve fatores diversos e enfrenta, ainda conforme Butler (2003, p. 57), "uma prática reguladora que busca uniformizar a identidade do gênero por via da heterossexualidade compulsória", com vistas a manter padrões e excluir lugares subversivos de sua convergência e ressignificação".

A violência de gênero aparece como um desses movimentos regulatórios à medida que impõe o que pode ou não, pela força física, moral, econômica, jurídica, religiosa, além do lugar de cada um na sociedade. É capaz de atingir indivíduos e coletividades, com referenciais relativos a sexo ou gênero.

Os signatários da Convenção Interamericana para Prevenir, Punir e Erradicar a Violência Contra a Mulher, entre os quais o Brasil, "afirmam que a violência contra a mulher constitui violação dos direitos humanos e liberdades fundamentais", bem como "manifestação das relações de poder historicamente desiguais entre mulheres e homens" (BRASIL, 1996, n.p.).

Tudo o que viola os direitos humanos, viola a democracia, palavra que remete a uma pluralidade de conceitos, perspectivas e modelos elaborados, revistos e (re)contextualizados desde a primeira experiência democrática, por volta de 500 a.C. Desse modo, pode ser abordada na concepção de determinado povo ou da comunidade global, das esquerdas ou das direitas, do socialismo ou do capitalismo, do patrão ou do empregado, do governante ou do opositor.

Sua conformação primária guardava a noção de que o governante deve agir conforme a maioria dos cidadãos, categoria que na Grécia Antiga se resumia à 
elite masculina. Viu-se, depois, que ouvir parcela da sociedade não bastava. Era indispensável estabelecer regras para legitimar a ascensão de alguém ao poder e garantir a estabilidade da relação entre povo e representantes.

O conceito original de democracia, o de forma de governo em que as decisões obedecem à vontade popular, está assim inscrito no parágrafo único do art. $1^{\mathrm{o}}$ da Constituição Federal brasileira: "Todo o poder emana do povo, que o exerce por meio de representantes eleitos ou diretamente, nos termos desta Constituição" (BRASIL, 2016, p. 11).

O trecho preocupa-se também com outro aspecto, o de que o exercício do poder, no território nacional, subordina-se a um "conjunto das leis fundamentais que regem a vida de uma nação, regula as relações entre governantes e governados, traçando limites entre os poderes e declarando os direitos e garantias individuais" (HOUAISS, 2009).

Desde as formas diretas de exercício do poder pelos cidadãos até as modalidades representativas, a vivência democrática sempre foi marcada pelo dinamismo. Por isso, é sentida a depender também do tempo e do espaço. Fenômeno natural, consoante Bobbio, (1986, p. 7), pois, sendo ela dinâmica, "o estar em transformação é seu estado natural". O contrário, o "estático e sempre igual a si mesmo", corresponde ao despotismo.

O império da lei ganha corpo no Estado Democrático de Direito que, por sua vez, tem por base os direitos fundamentais. "Ao longo da história", enfatiza Tavares (2020, p. 442), "assistiu-se à consagração", como direito humano, "dos direitos civis, dos direitos políticos, dos direitos sociais básicos e econômicos, dos direitos coletivos e, mais modernamente, dos direitos das minorias, do direito ao desarmamento etc".

Ressalta-se, ainda com apoio de Tavares (2020), que a democracia é em si um direito fundamental. Existem, segundo o autor, quatro dimensões de prerrogativas basilares. Na primeira, estão direitos individuais e políticos, a segunda é a dos direitos sociais, a terceira alberga direitos difusos e coletivos, enquanto a última, proposta por Bonavides (2015), protege democracia, pluralismo e informação.

Hoje, portanto, o corpo democrático é inseparável do espírito dos direitos fundamentais. Assim, a plenitude do regime pressupõe o fim da injustiça social e, como afirma Butler (2015, web), "Não há justiça social com discriminação de gênero", a exemplo dos ataques desferidos contra Patrícia Campos Mello. 
A segmentação produzida pelo machismo' ${ }^{1}$, de acordo com Saffioti (1987, p. 24), "compromete negativamente o resultado das lutas pela democracia, pois se alcança, no máximo, uma democracia pela metade". Ainda segundo a autora, mesmo que as mulheres percam mais que os homens, estes "continuarão a ter sua personalidade amputada", redundando em perdas para todos.

Alexy $(2015$, p.27), a propósito, assevera que o "direito racional moderno" exige, associadas à principiologia, definições "sobre os fins do Estado, a estrutura da democracia, do Estado de Direito e do Estado Social". Na visão de Bobbio (1986), passa também pela participação do maior número de atores sociais, a fim de que as decisões coletivas sejam inclusivas.

Participação ampla não se confunde com prevalência da vontade da maioria, seja essa maioria relativa ao poder ou ao número de seus formadores. De certo, é impositiva em determinados casos, a exemplo da eleição para escolha de representantes e das decisões para as quais a lei exige plebiscito ou referendo, mas nunca quando atropela direitos fundamentais das minorias ${ }^{2}$.

Não à toa, ao citar e comentar Zacher, Alexis (2015, p. 425) destaca "que a 'tarefa clássica dos direitos fundamentais na democracia' é a proteção das minorias". Então, se for encarada como insuperável, mesmo em afronta aos direitos fundamentais das minorias, a vontade da maioria sedimentará uma espécie de ditadura em função de elementos relacionados a sexo, gênero, religião, raça, cor, procedência nacional.

A tentativa de opressão das minorias ou de um de seus integrantes, por meio de expedientes racistas, homofóbicos e misóginos é tão grave para a estabilidade democrática e a paz social quanto o ataque direto ao regime democrático contido na defesa do populismo, do messianismo e do totalitarismo. Todos atingem o alicerce do edifício democrático mitigando a igualdade, a liberdade e a dignidade.

Aí surge um intrigante paradoxo: não há reação possível a tais posturas fora dos limites da lei, sob pena de se criar uma ditadura semelhante ao Apartheid, na África do Sul, em que a minoria numérica branca oprimia a maioria numérica negra; e a lei, no Brasil, garante a todos a liberdade de expressão que protege também os que proferem discursos contra a democracia e se opõem a valores dos grupos minoritários.

\footnotetext{
1. Machismo, para efeito desta pesquisa, é compreendido como "sistema de representações simbólicas, que mistifica as relações de exploração, de dominação, de sujeição entre o homem e a mulher" (DUMONT, 1980, p. 1); é, em complemento, "comportamento que tende a negar à mulher a extensão de prerrogativas ou direitos do homem" (HOUAISS, 2009, n.p.).

2. As expressões minoria e maioria indicam em alguns casos a quantidade de indivíduos e, em outros, o poder de dominação.
} 
A situação remete a Todorov (2012, p. 15), para quem a democracia engendra "seus próprios inimigos" e "produz, nela mesma, forças que a ameaçam". Por assim dizer, toda democracia é frágil em menor ou maior proporção, seja pelos choques entre seus segmentos, seja pelas liberdades dela provenientes, seja por tolerância a quem a rechaça.

Toda democracia é frágil também porque fundada em um contrato social, representação da "tensão dialética entre regulação social e emancipação social que se produz pela polarização constante entre o interesse individual e a vontade geral, entre o interesse particular e o bem comum" (SANTOS, 2016, p. 5). No mesmo lugar, em meio a relações diversas, ocorrem as tensões gerais entre exclusão e inclusão.

O Estado brasileiro está longe de promover uma igualdade real, embora formalmente todos sejam iguais perante a lei. A fragmentação da sociedade, "dividida em múltiplos apartheids, polarizada ao longo dos eixos econômicos, sociais, políticos e culturais" (SANTOS, 2016, p. 16), é visível em manifestações de grupos com declaradas ideias racistas, misóginas, homofóbicas e até nazistas.

Então, sendo a violência baseada no gênero encarada como desrespeito aos direitos fundamentais, alicerces do regime democrático, os enunciados que compõem as ofensas dirigidas à jornalista podem traduzir sentidos dos quais emergem sintomas de uma democracia frágil. E, se Patrícia, que ocupa posição de destaque no maior jornal do País, foi vítima de atos dessa ordem, imagina-se a que estão sujeitas brasileiras anônimas, nas relações familiares, de trabalho e demais vinculações sociais, como reflexo de um sistema político em que o poder é distribuído de forma muito desigual.

\section{PRÁTICAS DISCURSIVAS: RESISTÊNCIA E PRODUÇÃO DA VERDADE}

Na seção anterior, demonstrou-se que Patrícia Campos Mello sofreu violência de gênero, segundo a doutrina democrática. Viu-se também que esse tipo de acontecimento realça a fragilidade da democracia brasileira por ferir o pressuposto maior do regime: a igualdade entre os seres humanos, sem distinção de qualquer natureza.

Passa-se agora a dissertar sobre discurso, poder e resistência no mesmo cenário conflituoso. O objetivo é estabelecer, a partir de teorizações foucaultianas, como serão identificadas e analisadas as relações de poder e resistência materializadas nos enunciados que formam o corpus, observando-se aspectos históricos e sociais relativos ao machismo e aos embates políticos brasileiros da contemporaneidade. 
Discurso, na perspectiva de Foucault (2004, p. 8-9), é o conjunto de enunciados produzidos sob influência do meio social e da história, com mecanismos de controle, seleção, organização e redistribuição. Além disso, ele é marcado por procedimentos que "têm por função conjurar seus poderes e perigos, dominar seu acontecimento aleatório, esquivar sua pesada e temível materialidade".

Sua análise abrange dois níveis. O primeiro, denominado "arqueologia do saber", é "o balizamento e a descrição dos tipos". O segundo, chamado "dinástica do saber", corresponde à "relação entre esses grandes tipos de discurso que podem ser observados em uma cultura e as condições históricas, as condições econômicas, as condições políticas de seu aparecimento e de sua formação" (FOUCAULT, 2006, p. 49).

Na visão de Foucault (2005), a propósito, o poder não é uma entidade monolítica que espalha sua força persuasiva em sentido unilateral do centro para as periferias. Também não é polarizado, porque suas relações envolvem diversos micropoderes exercidos por diversos indivíduos, de formas múltiplas e em posições variadas. Não é distribuído de maneira democrática nem anárquica.

Os mecanismos de poder e a forma de seu exercício são, a exemplo do discurso, uma construção histórica e cultural, recomendando-se, a quem se propõe a estudar linguagem sob tal perspectiva, caracterizar como servem ou são "investidos, colonizados, utilizados, inflectidos, transformados, deslocados, entendidos etc" (FOUCAULT, 2005, p. 36), inclusive diante do fenômeno da resistência.

Discurso e poder são vetores mútuos. Daí Foucault (2006, p. 253) afirmar que não se ocupa na tentativa de "encontrar, por trás do discurso, alguma coisa que seria o poder e sua fonte", e sim partir "do discurso tal qual ele é!". Não importa o sujeito da fala, importa como o discurso funciona estratégica e sistematicamente nas cadeias, nos entrelaçamentos, nas relações de poder.

É igualmente importante decifrar como o poder se serve de práticas discursivas que produzem sentidos de resistência encarnados pela repórter e se essa oposição de fato inaugura ou ao menos favorece o surgimento de novos espaços de luta e transformação. Aliás, teria o discurso jornalístico maior capacidade de propagar e estabelecer suas verdades, estimulando outros poderes e resistências?

Na interpretação de Revel (2005, p. 74), a resistência foucaultiana acontece, "necessariamente, onde há poder, porque ela é inseparável das relações de poder; assim, tanto a resistência funda as relações de poder, quanto ela é, às vezes, o resultado dessas relações". O discurso de resistência, conforme o autor, torna possível a criação de espaços de luta e o agenciamento de transformações. 
Buscando diretamente em Foucault (2007), percebe-se que a resistência é contemporânea e, de certa forma, igual ao poder a que se contrapõe. Ambos se movem no tabuleiro servindo-se de estratégia, produtividade, inventividade e distributividade. Além disso, há uma espécie de via de mão dupla: o poder funda a resistência e a resistência inaugura relações de poder.

A análise do poder em si e do poder da resistência, realizada neste artigo, não se ocupa de formulações do direito - quanto ao que é lícito ou ilícito. O estudo, seguindo a orientação de Foucault em entrevista a Rabinow e Dreyfus (1995, p. 234), usa "as formas de resistência contra as diferentes formas de poder como um ponto de partida" e antagoniza as estratégias discursivas das personagens.

Aqui, o ponto de partida é a relação que envolve, de um lado, o uso de discursividades machistas como estratégias de poder e dominação e, de outro, táticas discursivas de resistência empregadas pela repórter da Folha, sem desconsiderar, na produção de verdades, influências históricas e do contexto social da democracia brasileira fragilizada pela violência de gênero.

"Estudar nessas práticas discursivas as regras, o jogo do verdadeiro e do falso", diz Foucault (2013, p. 6), é tanto interessante quanto revelador. Ainda mais quando a análise se desenrola no choque de enunciados produzidos por duas fontes com elevado potencial de influenciar o regime de veridicção: o poder político e a mídia, ambos com a pretensão de convencer a opinião pública.

Na visão de Foucault (2014, p. 4), é relevante investigar a "produção da verdade", observando-se "as estruturas próprias dos diferentes discursos que se propõem e são recebidos como discursos verdadeiros"; bem assimt como entender "sob que forma, em seu ato de dizer a verdade, o sujeito" - River, Bolsonaro, Patrícia, Folba -"constitui ou é constituído pelos outros como sujeito que pronuncia um discurso de verdade".

\section{BALIZAMENTO E DESCRIÇÃO DOS TIPOS DE DISCURSO: INSTRUMENTOS DE DOMINAÇÃO E PRÁTICAS DE RESISTÊNCIA}

Os textos aqui analisados apresentam características de tipos diferentes de discursivos, entre os quais o político, o jornalístico e o do ódio nas redes sociais, cada qual com características e verdades próprias. Por outro ângulo, desvelam relações de poder e resistência contidas nos enunciados produzidos pelos participantes.

O discurso político é espaço profícuo para os jogos da verdade, em que a disputa pelo poder se baseia mais nas versões do que nos fatos. $\mathrm{O}$ convencimento decorre do domínio da retórica, na escolha das palavras certas com efeitos de 
sentidos dirigidos ao que o interlocutor deseja ouvir. Serve-se de tudo na busca pela consagração enquanto verdadeiro: costumes, religiões, sexualidades.

Se está correta a afirmação segundo a qual "Somos submetidos pelo poder à produção da verdade e só podemos exercer o poder mediante a produção da verdade" (FOUCAULT, 2005, p. 28-29), o agente político se habilita a representar o povo quando consegue fazer valer as suas verdades sobre as verdades dos adversários.

No jornalismo, a verdade é o centro de todas as discursividades, afinal, o senso comum é o de que o jornalista deve produzir textos objetivos e imparciais. A imagem predominante confere às suas enunciações compromisso com a realidade fática, o que facilita o convencimento do público sobre a veracidade de uma informação veiculada na mídia tradicional (rádio, jornal, TV, revista).

Igual ao discurso político, contudo, o discurso jornalístico obedece a critérios subjetivos social e historicamente constituídos. Traquina (2005, v.1) lembra que, ao jornalista, atribui-se não apenas o papel de informar de maneira fidedigna. Na teoria democrática, diz ele, a imprensa é os olhos e a voz do povo para fiscalizar o poder instituído, divulgando, fiscalizando e denunciando.

Abramo (2003, p. 23) não desconhece esse papel social, mas é contundente ao afirmar que "Uma das principais características do jornalismo no Brasil, hoje, praticado pela maioria da grande imprensa, é a manipulação da informação". Essa manipulação, assegura, é um indício de que "os órgãos de comunicação se transformaram em novos órgãos de poder, em órgãos político-partidários".

$\mathrm{O}$ discurso do ódio também tem tudo a ver com o discurso político e com a disputa do verdadeiro. Meyer-Pflug (2009. p. 97) o conceitua como a enunciação de "ideias que incitem a discriminação racial, social ou religiosa em determinados grupos, na maioria das vezes, as minorias". Na prática, os dois funcionam em conjunto, em especial quando utilizados no intuito de dominação nas relações de poder.

Manifestações discursivas híbridas, com efeitos de sentidos ao mesmo tempo político e de ódio, sempre existiram e estão por toda parte, embora atinjam maiores proporções, ironicamente, com a liberdade de expressão das democracias e as possibilidades espaço-temporais da Internet. Qualquer pessoa pode ter uma rede social, dizer ali o que quiser e, de repente, ser percebida em várias partes do mundo.

Quando se exteriorizam em práticas discriminatórias, remetem ao que Foucault (2005) rotula de racismo biológico-social chantado no sentimento de que determinada categoria de indivíduos, por sua condição biológica - negro/branco, 
homem/mulher - pode ser superior a outra, por ser, nas relações sociais, "aquela que detém o poder, aquela que é titular da norma" (FOUCAULT, 2005, p. 72-73).

Assim, caracterizados os tipos de discurso como primeira etapa da metodologia proposta por Foucault (2006), é chegada a hora de analisar, a partir do caso concreto, as condições políticas do aparecimento e da formação de discursividades machistas empregadas contra Patrícia Campos Mello, bem como as estratégias discursivas de resistência utilizadas pela jornalista.

\subsection{Estratégias discursivas machistas em enunciados de Hans River, Jair Bolsonaro e internautas}

A fala de Hans River na CPMI das Fake News poderia ser enquadrada como discurso jurídico, afinal fora ele ouvido como testemunha. Ocorre que o efeito de sentido aparentemente desejado, ao ofender a repórter, era o de produzir um fato político capaz de desacreditar a matéria escrita por ela, na disputa entre falso e verdadeiro, para beneficiar o presidente da República perante a opinião pública.

Discurso e poder, já se disse, influenciam-se mutuamente num jogo de veridicção que se desenrola em situações contextualizadas. Quando disse aos parlamentares da CPMI das Fake News que Patrícia "queria um determinado tipo de matéria a troco de sexo", Hans (2020, n.p.) serviu-se de estratégia discursiva comum ao machismo: a de utilizar a sexualidade para reduzir a condição feminina.

A conotação erótica atribuída ao contato feito pela repórter, que parece ter o objetivo de humilhá-la e, assim, reduzir seu papel profissional, não nasceu ali, naquele depoimento. Está arraigada a uma memória discursiva acionada sempre que alguém deseja botar a mulber no seu lugar para cumprir um papel definido por práticas discursivas históricas, culturais, religiosas, políticas.

A origem está na repressão promovida por sociedades, governos, sistemas religiosos, instituições diversas e até no ambiente familiar. Há séculos, não obstante as evoluções e conquistas, a sexualidade feminina é marcada pela exigência da castidade e o objetivo da reprodução. Aquela que se desaloca dos padrões arriscase a perder o respeito das pessoas com as quais convive.

Por isso, nas democracias fragilizadas por práticas misóginas, entre as quais o machismo, uma das formas de tentar desacreditar a mulher nas relações de poder desenvolvidas em qualquer segmento é atribuir a ela, como fez Hans, uma conduta sexual inadequada. No caso, uma conduta profissional consistente em pagar pela notícia, e pagar com sexo, produzindo discursivamente um sujeito moralmente corrompido. 
O ponto de vista é corroborado pela International Women's Media Foundation. Em nota de apoio a Patrícia, a entidade, focada em estimular mundialmente o trabalho de mulheres jornalistas, afirma que $70 \%$ das profissionais do setor já sofreram assédios, ameaças e ataques (IWMF, 2020).

A questão, de fato, não se restringe ao Brasil. A relatora especial das Nações Unidas sobre Violência contra a Mulher, Dubravka Simonovic (2020), centrou seu informe de 2020 ao Conselho de Direitos Humanos da Organização das Nações Unidas (ONU) nas intimidações e ameaças a mulheres jornalistas, registrando que uma em cada três sofre violência de gênero.

Resguardadas as proporções, o impulso histórico-político-cultural que envolve o argumento de Hans é o mesmo revelado em situações nas quais a mulher vítima de violência é apontada como causadora da violência que sofreu. A chance de estratégias assim funcionarem é grande, porque, no machismo estrutural, encontram-se tanto homens quanto mulheres machistas.

As postagens de redes sociais contra Patrícia se compõem de enunciados que refletem sentidos de discurso de ódio, mas também não deixam de ter viés político. O difícil, para o internauta comum, é saber se ataques dessa ordem provêm de pessoas de verdade ou de contas falsas, os chamados robôs, criados muitas vezes para o cometimento de cibercrimes.

Nessa relação, o discurso político constrói sentidos que podem descredenciar o discurso jornalístico, atingindo-o no âmago a fim de descontruir sua imagem enquanto emissor da realidade, imputando a tudo que o desagrada, o rótulo de fakenews. Na empreitada, por meio de seguidores de verdade ou de robôs, de informações verdadeiras ou falsas, serve-se sempre de elementos culturais.

Muitas pessoas aderem e se identificam com essas verdades centradas na violência de gênero e de outras modalidades de fragilização da democracia. Defendendo a Ditadura Militar, pronunciando frases misóginas e homofóbicas, Jair Bolsonaro foi vereador do Rio de Janeiro em 1988, deputado federal por sete vezes, de 1991 a 2018 e presidente da República em 2018, com 55,13\% dos votos.

Os resultados são indícios contundentes de que parcela considerável da população brasileira se identifica com a estratégia discursiva do bolsonarismo. Uma identificação muitas vezes inconsciente, arraigada social, histórica e culturalmente, que favorece a dominação a partir de práticas discursivas machistas nas relações de poder com vistas ao predomínio de verdades junto à opinião pública. 


\subsection{Estratégias discursivas de resistência e veridicção no artigo de Patrícia Campos Mello}

Em contraponto aos enunciados de Hans, do presidente e de internautas, Patrícia Campos Mello escreveu um artigo, gênero jornalístico opinativo, em que valoriza discursos de verdade ressaltando funções sociais do jornalismo, especialmente as de fiscalizar o poder e informar de maneira fidedigna.

Ao mesmo tempo em que se defende, a jornalista revida com estratégias discursivas de resistência e veridicção centradas no contexto sócio-histórico das relações de poder entre homens e mulheres, enfatizando a autoridade de quem, sentindo na pele o preconceito, carrega consigo tais verdades.

Desde o título - Depoimento: No Brasil, ser mulher nos transforma em alvo de ataques -, com a utilização do substantivo "depoimento" e do pronome "nos" (MELLO, 2020, n.p.), a repórter se posiciona discursivamente em relação ao sexo biológico. De tal modo, apresenta-se aos leitores na condição de quem tem capacidade especial de falar sobre o tema por ser participante ativa daquela relação de poder, com domínio sobre a verdade.

A autoafirmação da experiência é uma marca discursiva útil no convencimento do outro. Não à toa, o jornalista, no exercício profissional, costuma embasar argumentos na voz da autoridade. Busca-se sempre uma fonte especializada no tema abordado, a fim de conferir credibilidade ao material jornalístico.

A expressão especializada, vista no parágrafo anterior, refere-se tanto ao título acadêmico quando à imersão da fonte em certas realidades. Ser mulher, trabalhadora, repórter, constitui subjetividades que conferem autoridade para comentar temas relacionados ao universo feminino, a exemplo do machismo no ambiente de trabalho. Quem sabe é quem vive; e saber, diz Foucault (2004), é poder.

Não é diferente do que Patrícia faz como prática de resistência ao machismo de que denuncia haver sido vítima. A posição de cada indivíduo, conforme Foucault, nas palavras de Brandão (2004, p. 37), pode ser observada como:

[...] jogo estratégico e polêmico... de ação e de reação, de pergunta e resposta, de dominação e de esquiva e também como luta [...]. É o espaço em que saber e poder se articulam, pois quem fala, fala de algum lugar, a partir de um direito reconhecido institucionalmente. Esse discurso, que passa por verdadeiro, que veicula saber (o saber institucional), é gerador de poder.

No subtítulo - Tem gente que vê graça em linchamento misógino; o que achariam se a piada fosse com a filha deles? (MELLO, 2020, n.p.) -, o jogo estratégico e polêmico de resistência e verdade prossegue, mas pelo viés dos agressores - os outros -, a partir 
das vivências deles com as mulheres da própria família, o que se faz na articulação de uma afirmativa com um questionamento.

Assim, além de confrontar os detratores, a jornalista produz um efeito de atração da solidariedade das leitoras e dos leitores, perspectiva com a qual passa a narrar o que disseram a respeito dela, e que poderia ser com qualquer mulher, filha, mãe, irmã, amiga, de qualquer um:

Quanto valerá uma foto em que uma mulher aparece pelada, de pernas abertas, em cima de
uma pilha de notas de dólares, chamada de piranha? E uma em que o rosto dessa mesma
mulher aparece com a legenda: "Folha da Puta - tudo por um furo, você quer o meu? Patrícia,
Prostituta da Folba de S.Paulo - troco sexo por informações sobre Bolsonaro"? E outra em que
essa mulher - sempre a mesma - aparece com a frase: "Ofereço o cuzinho em troca de
informação sobre o governo Bozo"? (MELLO, 2020, n.p.)

A articulista pede desculpas pelas "palavras grosseiras", forma indireta de enfatizar a gravidade das ofensas, revela que tais expressões de ódio foram compartilhadas por milhares nas redes sociais, como brincadeira, e volta a questionar: "Será que esse pessoal acharia graça se essa 'piada' fosse com a irmã, a mulher ou a filha deles?" (MELLO, 2020, n.p.).

Após a primeira etapa desse jogo discursivo estratégico, em que ação e reação centram-se na empatia e na vivência como signo de autoridade, Patrícia, sugere o texto, parte para a dicotomia verdade/mentira. A verdade está com ela, que escreveu matérias respaldadas em fontes insuspeitas, inferindo desde logo que Hans mentiu à CPMI. Observe-se:

A reportagem, baseada em documentos públicos da Justiça do Trabalho, fotos, planilha e em relatos de Hans mostrou que uma rede de empresas, entre elas a Yacows, recorreu ao uso fraudulento de nome e CPFs de idosos para registrar chips de celular e garantir o disparo de lotes de mensagens em benefício de políticos (MELLO, 2020, n.p.).

A ênfase ao caráter público dos documentos - e mais ainda à fonte de produção dos citados papéis, a Justiça do Trabalho - leva à reflexão sobre uma tentativa de garantir a credibilidade da informação em contraponto às inverdades de Hans, agora chamado literalmente de mentiroso:

Em seu depoimento à CPMI, Hans contou diversas mentiras(https://www1.Folha.uol. com.br/poder/2020/02/ex-funcionario-de-empresa-de-disparo-em-massa-mente-a-cpi-einsultareporter-da-Folha.shtml), entre elas a de que eu teria tentado obter informação "a troco de sexo" (MELLO, 2020, n.p.).

O jornalista, explica Bonfim (2002, p. 25), promove a mediação entre os acontecimentos e o receptor. Nesse processo, que nunca será neutro, ele seleciona e recorta as manifestações das fontes. A dispersão de sujeitos, aqui a Justiça do 
Trabalho e a Folba, é usada para refutar ou legitimar determinado discurso, para chancelar "os pontos de vista da empresa jornalística e de seus associados".

A notícia, afirma Traquina (2005, p. 28), é "uma 'construção', o resultado de inúmeras interações entre diversos agentes sociais que pretendem mobilizar as notícias como um recurso social em prol das suas estratégias". Nessa perspectiva, as explicações de Patrícia sobre a produção da matéria é um jogo estratégico. Além do verdadeiro e do falso, há intencionalidades na escolha por tornar públicas determinadas vozes. Também circunstâncias, como a revelação de que as entrevistas de Hans foram gravadas.

O gravador é uma das armas do repórter na comprovação da verdade. Certo ou não de que sua entrevista fora gravada, e mesmo duvidando, dificilmente uma fonte que mentiu se volta contra o repórter, temendo ser desmentida.

Um último enunciado é igualmente importante para tentar convencer o leitor sobre quem está com a verdade: "Tudo isso foi anexado ao processo que estou movendo contra ele" (MELLO, 2020, n.p.). De novo, a Justiça como garantidora do verdadeiro ganha ênfase no discurso e é reafirmada como queixa de que, apesar de as falas de Hans terem sido comprovadas como falsas, os Bolsonaros as replicaram.

Nada disso importou. O deputado Eduardo Bolsonaro [...] Fez vídeo ecoando a mentira e distribuiu em suas redes sociais. Reproduziu as ofensas de Hans em diversos comentários em sua conta do Twitter, que tem 1,8 milhão de seguidores. Fez questão de subir na tribuna da Câmara dos Deputados e dizer, enquanto era filmado: "Eu não duvido que a senhora Patrícia Campos Mello, jornalista da Folba, possa ter se insinuado sexualmente, como disse o senhor Hans, em troca de informações para tentar prejudicar a campanha do presidente Jair Bolsonaro" (MELLO, 2020, n.p.).

Os Bolsonaros não mentiram. Serviram-se de um fato real, embora partindo de assertivas controversas, com a finalidade de desacreditar matérias da Folha que os atingiam. Afinal, no jogo do poder político, ainda vale a máxima atribuída a José Maria Alkmim, vice-presidente do Brasil (1964 a 1967), por Silveira (in NERY, 2000, p. 13): "O importante não é o fato, mas a versão do fato".

A questão é que, em tempos de redes sociais e de robôs, manifestações como as do deputado e do presidente provocam repercussões imediatas, sobretudo por seguidores. Essas repercussões se materializaram, como ressalta Patrícia (2020, n. p), "Além dos inúmeros memes de cunho pornográfico, recebi mensagens agressivas", os quais passa a transcrever, textualmente, identificando os autores:

Você tava querendo dar a buceta para ver o notebook do cara kkkkkkkentão você chupa piroca por fontes?", dizia um usuário do Facebook chamado Bruno Pires, que, segundo sua conta na rede social, estudou direito na Universidade de Rio Verde. 


\begin{abstract}
"Puta do caralho, por que você não libera seus comentários? Quem tem cu, tem medo", disse um Luciano Marrtins, de Santo André, em mensagem enviada por Facebook.

$[\ldots]$

"E aí, putinha da Folha, kkkkk, cuidado ao oferecer o furico", disse o usuário matheus.schuler, no Instagram (MELLO, 2020, n.p.).
\end{abstract}

A identificação de hipotéticos agressores os expõe em seus ciclos de convivência, enquanto a transcrição dos enunciados, que traduzem efeitos de sentimento de ódio, pode ser vista como manobra discursiva de garantia da verdade e estratégia de reação. Reproduzir, sem subterfúgios, expressões incomuns a um veículo tradicional, tanto revela a gravidade dos ataques quanto a coragem e o poder de resistência da mulher que se desenha na superfície e nas entrelinhas do texto.

Práticas discursivas de resistência presentes desde o início do artigo na autoidentificação da autora e no enfrentamento de acusações e xingamentos, ganham contornos de sentidos também quando Patrícia descreve sua experiência profissional na cobertura de conflitos e guerras. Evocam, inclusive, a condição feminina como inspiradora de confiança. A saber:

Em palestras e aulas, muitas pessoas me perguntam quais as dificuldades que uma mulher jornalista enfrenta para cobrir conflitos ou guerras ao redordo mundo.

Eu costumava responder que, na nossa profissão, ser mulher mais ajuda do que atrapalha. Nós temos o privilégio de poder conversar livremente com outras mulheres, entrar em suas casas, ter um pouco mais de contato com o dia a dia delas, mesmo em países mais conservadores - ao contrário dejornalistas homens.

Acredito que, em muitas das reportagens que tive a oportunidade de fazer - desde a cobertura de conflitos na Síria, Líbia, Iraque e Afeganistão até a epidemia de ebola em Serra Leoa (https://www1.Folha.uol.com.br/mundo/2016/01/1729884-serra-leoaregistra-caso-deebola-apos-regiao-ser-considerada-livre-do-virus.shtml), com temas difíceis como estupro e agressões contra refugiados - o fato de ser mulher foi uma vantagem. Acho que me ajudou a pelo menos tentar ter mais empatia e mecolocar no lugar de todas essas pessoas que tentam sobreviver em circunstâncias muito difíceis (MELLO, 2020, n.p.).

Observa-se que Patrícia fornece links por meio dos quais o leitor tem acesso a reportagens feitas por ela. Essa atitude constrói subjetividades que a inscrevem como profissional experiente, digna da credibilidade de pessoas em situação de vulnerabilidade e, por conseguinte, de toda espécie de fonte e de leitor. Contudo, segundo diz, no Brasil, pouco importa a competência em dado ofício. Para a jornalista, o simples fato de ser mulher transforma o ser humano em alvo de ofensas preconceituosas com emprego de expressões que atingem inclusive seus familiares. Nas palavras dela:

No Brasil, longe desses conflitos, estamos descobrindo que ser mulher nos transforma em alvos. As agressões que sofremos têm sempre uma conotação preconceituosa: dizem que as jornalistas são feias, gordas, velhas ou prostitutas; expõem seus filhos, maridos ou pais. 
Eu não fui a primeira e não serei a última mulher a sofrer ataques misóginos simplesmente por fazer jornalismo no Brasil (MELLO, 2020, n.p.).

Após declarar que não foi a primeira nem será a última, Patrícia cita os episódios em que Talita Fernandes, Vera Magalhães, Marina Dias, Constança Rezende e Míriam Leitão foram alvos do presidente e de seus seguidores, mas lembra que a resistência existe:

Pessoas de todos os cantos do espectro ideológico, da direita à esquerda, associações cristãs, judaicas, de advogados, de mulheres empresárias, atrizes e artistas, estudantes, gente da periferia e dos bairros ricos" manifestaram-se "para repudiar o desrespeito às mulheres (MELLO, 2020, n.p.).

O artigo de Patrícia se estabelece na relação de poder que a envolve, ao presidente, a Hans River e a internautas - reais e robôs - como uma demonstração de resistência e de criação de espaços de contestação. Daí a solidariedade oriunda desde mulheres comuns até representantes de entidades internacionais. Não se pode olvidar que a repórter de um grande jornal, mesmo em democracias frágeis em que o machismo está arraigado em todas as camadas, desempenha papel capaz de oferecer maior resistência.

A resistência da repórter, confirmando a tese foucaultiana reproduzida por Revel (2005), nasce no poder. Aqui, especificamente, na relação de poder estabelecida no confronto entre discurso político, discurso do ódio e discurso jornalístico.

Nesse jogo, o que se depreende é que o discurso de gênero surge como espécie de antídoto ao discurso jornalístico, em meio à disputa pela verdade. Atacou-se a repórter a partir de discursividades com efeitos de sentidos machistas presentes na cultura brasileira, inclusive na cultura política, fortalecendo a resistência encampada por ela, com adesão de várias entidades e pessoas.

A análise corrobora a afirmação de Foucault (2007), segundo a qual, a resistência é contemporânea ao poder e, na relação com ele estabelecida, a depender de estratégias, condições e distribuição, pode ocasionar mudanças em seu domínio, abrindo espaços de luta e transformação.

\section{CONSIDERAÇÕES FINAIS}

O arcabouço teórico e a abordagem analítica do corpus sustentam a conclusão de que uma democracia, para ser plena, deve consagrar a igualdade, a liberdade e a dignidade no plano jurídico e no mundo real. No Brasil, embora a Carta Magna 
assegure a igualdade de todos perante a lei, sem distinção de qualquer espécie, o machismo estrutural dificulta o acesso das mulheres ao exercício pleno da cidadania.

Os enunciados com efeitos de sentidos sexuais e as agressões dirigidas a Patrícia Campos Mello são um retrato dessa realidade. Se bem observadas, as estratégias discursivas miram a mulher, em razão do gênero, com o objetivo de desacreditar a profissional. A matéria da Folba de S.Paulo que inaugurou a polêmica é assinada também por Artur Rodrigues, mas ninguém usa a condição masculina para investir contra o jornalista.

Patrícia sofreu violência de gênero, pois os ataques dirigidos a ela são constituídos de enunciados cujos efeitos de sentidos resumem-se à condição feminina, como reflexo de discursividades constituídas socialmente ao longo da história. Tais construções formam a cultura de que, além das características anatômicas, homens e mulheres são diferentes, com vistas a justificar relações de dominação e desigualdade de fruição dos direitos fundamentais.

Os atos machistas dos quais foi vítima a repórter da Folba se instituem, portanto, como reflexo da fragilidade democrática brasileira, partindo do princípio de que, sendo a ação discriminatória física, econômica, jurídica, religiosa ou moral, a exemplo do que se percebe neste caso, acarretará sempre violação aos direitos humanos e prejuízo às liberdades fundamentais.

O episódio no qual se antagonizam, de um lado, Hans River, Jair Bolsonaro e internautas - tanto os verdadeiros quanto os robôs; e, de outro, Patrícia Campos Mello, revela, para lá das questões sociais, históricas e culturais, uma complexa relação discursiva na qual o poder e a resistência fundam-se mútua e constantemente em um jogo polêmico na disputa pela verdade.

As verdades valorizadas pelos contendores não chegam a ser novidade. Ambos os lados buscam discursividades latentes na cultura brasileira com o objetivo de conquistar a empatia da opinião pública. Nessa relação de poder e resistência, afloram com especial visibilidade, as verdades da cultura machista.

Então, vistas a evolução dos conceitos de democracia e direitos fundamentais, as concepções foucaultianas sobre discurso, poder e resistência e as condições de surgimento da relação estabelecida, compreende-se que, nas democracias frágeis, discursividades centradas no gênero emergem como estratégias de poder e dominação, mas também como tática de resistência e transformação. 


\section{REFERÊNCIAS}

ABRAMO, P. (2003). Padrões de manipulação na grande imprensa. São Paulo: Editora Fundação Perseu Abramo.

ALEXY, R. (2008). Teoria dos Direitos Fundamentais. Tradução de Virgílio Afonso da Silva. São Paulo: Malheiros, 2015.

BARREDA, V. (2012). Género y travestismo em el debate. In: OPIELA, C.V. (org). Derecho a la identidad de género: Ley no 26.743. Buenos Aires: La Ley, p. 99-106.

BOBBIO, N. (1984). O futuro da democracia - uma defesa das regras do jogo. Tradução de Marco Aurélio Nogueira. Rio de Janeiro: Paz e Terra, 1986.

BOLSONARO, J.M. Bolsonaro insulta repórter da Folba: "ela queria dar o furo". Disponível em: https://www.youtube.com/watch?v=znEDvZqXA_U Acesso em: 30mar. 2020.

BONAVIDES, P. (2015). Curso de Direito Constitucional. São Paulo: Malheiros Editores Ltda.

BONFIM, J. B. B. (2002). A fome que não sai no jornal - o discurso da mídia sobre a fome. Brasília: Plano.

BRANDÃO, H. H. N. (2004). Introdução à Análise do Discurso. Campinas-SP: Editora da Unicamp.

BRASIL. (1988). Constituição da República Federativa do Brasil. Brasília: Senado Federal, 2016.

BRASIL. (1996). Convenção Interamericana para Prevenir, Punir e Erradicar a Violência Contra a Mulber.

Disponível em: http://www.planalto.gov.br/ccivil_03/decreto/1996/D1973.htm Acesso em: 25 ag. 2020.

BUTLER, J. (1990). Problemas de gênero - feminismo e subversão da identidade. Tradução de Renato Aguiar. Rio de Janeiro: Civilização Brasileira, 2003.

BUTLER, J. (2015). "Não bá justiça social com discriminação de gênero", diz filósofa. Entrevista com Judith Buther conduzida por Isabel Palhares. Estado de São Paulo, 11 set. 2015. Disponível em:https://brasil.estadao.com.br/noticias/geral,justica-social-nao-virasem-o-fim-da-discriminacao-de-genero--diz-pesquisadora, 1760597? fbclid=IwAR 3X9cE4GjW8mNc_sqg8DsEhK1uS_MhDEMJBObX1QslUuTGchjB9ybgAW8 Acesso em:10ag. 2020. 
DREYFUS, H. L.; RABINOW, P. (1995). Michel Foncault: uma trajetória filosófica - para além do estruturalismo e da hermenêutica. Traduçãode Porto Carrero. Rio de Janeiro: Forense Universitária.

DUMONT, M. P. (1980). Elementos para uma análise do machismo. Perspectivas: São Paulo.

FOUCAULT, Michel. (1971). A ordem do discurso. Tradução de Laura Fraga de Almeida Sampaio. São Paulo: Loyola, 2004.

FOUCAULT, M. (1999). Em defesa da sociedade. Tradução Maria Ermantina Galvão. São Paulo: Martins Fontes, 2005.

FOUCAULT, M. (1994). Estratégia, Poder-Saber. Tradução de Vera Lúcia Avellar Ribeiro. Rio de Janeiro: Forense Universitária, 2006.

FOUCAULT, M. (1979). Microfísica do poder. Tradução de Roberto Machado. Rio de Janeiro: Graal, 2007.

FOUCAULT. M. (2010). O governo de si e dos outros. Tradução de Eduardo Brandão. São Paulo Paulo: Martins Fontes, 2013.

FOUCAULT, M. (2011). A coragem da verdade. Tradução de Eduardo Brandão. São Paulo: WMF Martins Santos, 2014.

HOUAISS, A. (2001). Dicionário Eletrônico Honaiss. Rio de Janeiro: Objetiva, 2009.

IWMF. (2020). A IWMF apoia Patrícia Campos Mello e condena os atadues contra mulberes jornalistas. Disponível em: https://www.iwmf.org/2020/02/the-iwmf-stands-with-patriciacampos-mello-and-condemns-attacks-against-women-journalists/ Acesso em: 10 ag. 2020 .

MELLO, P. C. de. (2020). Depoimento: No Brasil, ser mulher nos transforma em alvo de ataques - Tem gente que vê graça em linchamento misógino; o que achariam se a piada fosse com a filha deles? Disponível em: https://www1.folha.uol.com.br/ poder/2020/03/depoimento-no-brasil-ser-mulher-nos-transforma-em-alvo-deataques.shtml Acesso em: 30 mar. 2020.

MEYER-PFLUG, S. R. (2009). Liberdade de expressão e discurso do ódio. São Paulo: Revista dos Tribunais. 
NACIMENTO, H.R. do R. (2020). CPMI das Fake News - Oitiva de Hans River do Rio Nascimento-11/02/2020. Disponível em: https://www.youtube.com/ watch?v=iLozDVNk0WA Acesso em: 30mar. 2020.

REVEL, J. (2002). Foucault - conceitos essenciais. Tradução de Carlos Piovesani Filho e Nilton Milanez. São Carlos: Claraluz, 2005.

SAFFIOTI, H. I. B. (1987). O poder do macho. São Paulo: Moderna.

SANTOS, B. de S. (2016). A difícil democracia: reinventar as esquerdas. Rio de Janeiro: Boitempo.

SILVEIRA. E. (2000). Ética e jornalismo. In: NERY, S. Grandes pecados da imprensa. Geração Editorial: São Paulo, p. 13-14.

SIMONOVIC, D. (2020). Erradicación de laviolencia contra las periodistas. Informe de la Relatora Especial sobre laviolencia contra lamujer, sus causas y consecuencias. Disponível em: https://undocs.org/es/A/HRC/44/52 Acesso em: 20 jul. 2020.

TAVARES, A. R. (2020). Curso de direito constitucional. São Paulo: Saraiva.

TODOROV, T. (2012). Os inimigos íntimos da democracia. Tradução de Joana Angélica d'Avila Melo. São Paulo: Companhia das Letras.

TRAQUINA. N. (2005). Teorias do Jornalismo - Porque as notícias são como são. v.1. Florianópolis: Insular.

Recebido: 10/9/2020

Aceito: 3/11/2020

Publicado: 4/11/2020 